\title{
The Impact of Foreign Direct Investment on the Nigeria Manufacturing Sector: A Time Series Analysis
}

\author{
Rasaq Akonji Danmola \\ Adijat Olubukola Olateju \\ Faculty of Social Sciences, Department of Economics, \\ Lagos State University, Ojo, Lagos, Nigeria \\ Abubakar Wambai Aminu \\ Faculty of Social Sciences, Department of Economics, \\ Bayero University Kano, Kano State, Nigeria
}

Doi: 10.19044/esj.2017.v13n31p521 URL:http://dx.doi.org/10.19044/esj.2017.v13n31p521

\begin{abstract}
The objective of the study reveals that FDI in the Manufacturing sector exacts a positive influence on the manufacturing output and the impact is statistically significant. This result further confirms the effectiveness of economic policy of the federal government of Nigeria through the adoption of liberalized industrial and trade policies. These policies were undertaken with a view to improve efficiency and productivity, as well as to improve the competitiveness of the Nigerian manufacturing industry. The policy implication is that,in order to maintain sustainable economic growth and development, a positive domestic investment is a prerequisite for increasing the flow of foreign investment in the manufacturing sector. Nigeria, while continuing to encourage inward FDI, efforts should be made to channel it into the manufacturing sector so as to accelerate the diversification process. In addition, the implementation of policy of trade liberalization should be reviewed and implemented with caution. The policy that will further make the economy more-import dependent will not augur well for the economy.
\end{abstract}

Keywords: Foreign Direct Investment to Manufacturing sector (FDIm), Manufacturing output, Variance Decomposition, Impulse Response function.

\subsection{Introduction}

The manufacturing sector has been one of the major contributors to Nigeria's economic growth, but unfortunately, after witnessing tremendous growth between the mid-1970s and the1980s, the sector experienced serious stagnation, and for most of the 1980s and the1990s, Nigeria's productivity 
declined. This serious problem can be attributed to the downward trend in the global oil market and the consequent fall in oil prices. Governmentrevenue, coupled with foreign exchange earnings, weredrastically affected by the problems experienced in the oil market, and the government was therefore forced to adopt a series of economic reform policies such as austerity measures. This prevailing situation has negatively affected the manufacturing sector. In addition to this, serious trade control policies, like the rationing of foreign exchange, import restrictions via import licensing and tariff hikes, as well as quantitative measures, were put in place.

The above trade controls and industrial policies have causeda serious fall in foreign exchange allocation to this sector, and have led to a reduction in the importation of industrial raw-materials and spare parts available for production in the sector.Thecosts of importing these essential industrial inputs were prohibitive, and the foreign exchange needed for suchprocurement wasin short supply. The situation has resulted in widespread industrial closures, massive job cuts and a massive drop in capacity utilization. The sector recorded a fall in real output of 40 percent between 1994 and 1996 and, since then, the sector has continued to experience a downward trend in real output. The capacity utilization of the manufacturing sector has not moved above 80 percent at any time over the past thirty years, as can be seen in Figure 1

\section{Average Capacity Utilisation}

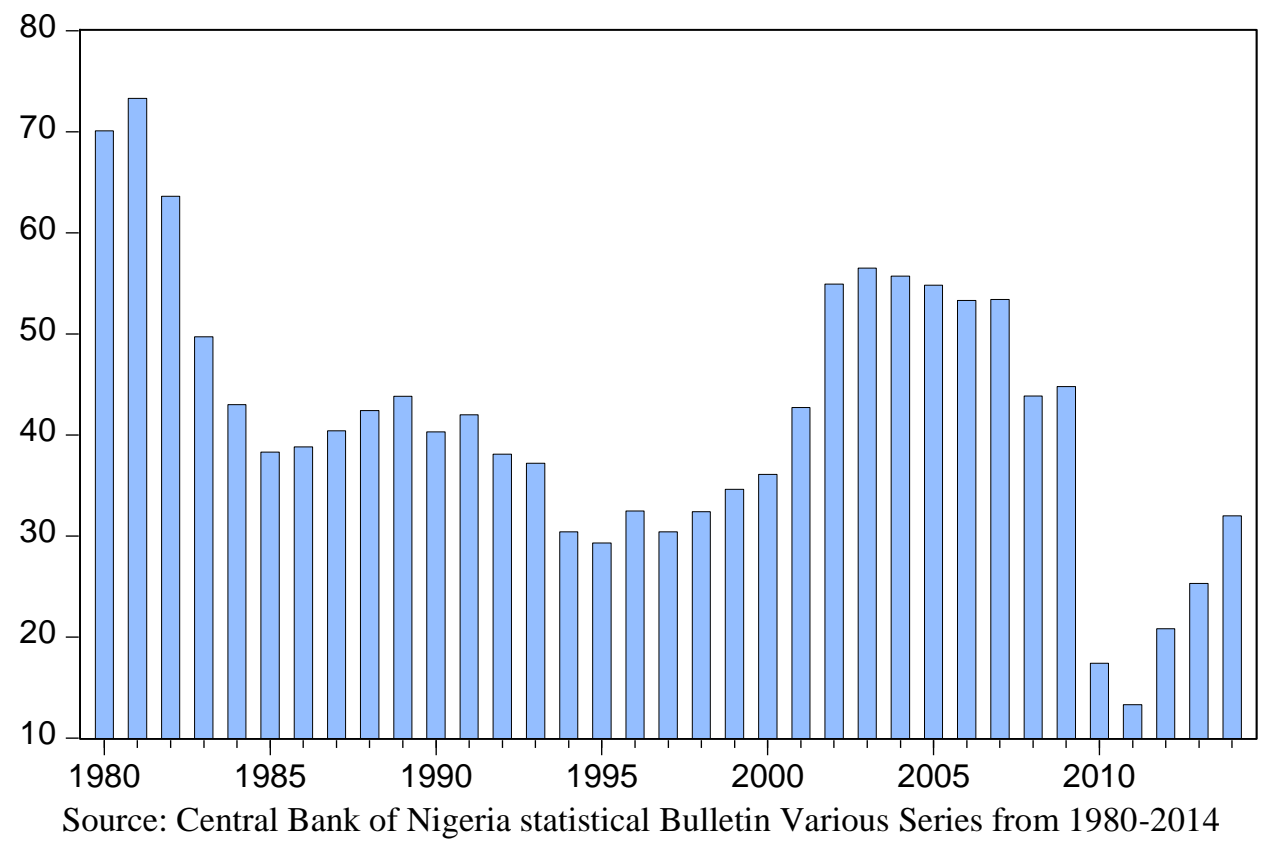

Figure 1: Average Capacity Utilization of Manufacturing Sector 1980-2014 
From Figure 1 above, the average capacity utilization in the manufacturing sector since 1984 has been less than 60 percent, and most manufacturing firms have been operating below production capacity; this has negatively affected the sector. This problem has made it difficult for firms to meet local demand, let alone to produce for export. The sector was confronted with a shortage of raw-material for production, and did not have the necessary foreign exchange for the importation of spare parts needed for production.

Apart from the above problems, the cost of doing business in the sector is high. To achieve a reasonable growth in the manufacturing sector, it has often been suggested that Nigeria, like other developing country, needs to embark on the intensive mobilization of both domestic and foreign capital in order to accelerate sustainable economic growth. However, a careful look at Table 1 below clearly shows that the cost of doing business is very high. Macroeconomic variables that are vital to the availability of financial resourcesinthe manufacturing sector are considered in Table 1. The macroeconomic variables considered include Gross Fixed Capital Formation-GDP ratio (GFCF/GDP), Savings-GDP ratio (SAV/GDP), Lending Rate (LR), and Credit to Private Sector-GDP ratio (CPS/GDP).

With this trend, meaningful investment could not be generated domestically and a large proportion of income was spent on consumption. The savings-GDP ratio reached 8.6 by 2002 and, by implication;a larger percentage of GDP went onconsumption before this figurerose to 37.78 in 2010. The credit available to the private sector was not encouraging and the ratio of the GDP fell to an all-time low of 12.8 in 1993.Equally, the issue of the mobilization of savings in the Nigerian economy left much to be desired. The savings-GDP ratio is abysmal and not encouraging.

Table 1 clearly shows that the Nigerian manufacturing sector is confronted with the problem of financial resources, which are in short supply. The ratio of gross fixed capital formation (that is, domestic investment) to GDP, for instance, fell to 5.5 in 2005, before it rose significantly in 2010 to 13.7 . In the same vein, the lending rate is prohibitive for any meaningful productive investment. Nigeria's lending rate reached its peak in 1993, when it was 36.09 percent (CBN, 2014). This lending rate does notgive room for any productive investment to take place, but is only good for the services sector, where quick rates of return are expected;it cannot propel any meaningful development in the manufacturing sector. 
Table 1: Nigeria's Selected Economic Indicators

\begin{tabular}{crrrr} 
Year & LR & GFCF/GDP & SAV/GDP & CSP/GDP \\
2000 & 21.3 & 7.2 & 8.4 & 12.3 \\
2001 & 23.4 & 7.2 & 10.3 & 15.2 \\
2002 & 24.8 & 7.9 & 8.6 & 13 \\
2003 & 20.7 & 10.2 & 7.7 & 13.8 \\
2004 & 19.2 & 7.6 & 7 & 13.1 \\
2005 & 16.9 & 5.5 & 9 & 13.3 \\
2006 & 16.9 & 8.3 & 9.4 & 13.3 \\
2007 & 15.5 & 9.4 & 13 & 25.3 \\
2008 & 18.4 & 8.4 & 16.9 & 33.9 \\
2009 & 17.6 & 12.2 & 23.2 & 38.9 \\
2010 & 14.1 & 13.7 & 20.4 & 29 \\
2011 & 21.8 & 14.6 & 19.5 & 30.1 \\
2012 & 22.6 & 15.2 & 17.4 & 33.9 \\
2013 & 23.9 & 16.1 & 18.5 & 35.2 \\
2014 & 14.1 & 10.2 & 21.8 & 36.1 \\
\multicolumn{2}{r}{ Source: Central Bank Statistical Bulletin of Various Issues from 2000-2014 } \\
\hline
\end{tabular}

In most developing countries, FDI can theoretically be employed to quicken the pace of industrial development, including in the manufacturing sector, by providing industry, capital infrastructure, employment, international market access, revenue and technology (Ratha, 2000). However, the disparity between the success and the failure of developing countries in practice to maximize the domestic gains and minimize the negative externalities of foreign investment extended the questions about the globalization of investment beyond thetheoretical frontiers. More particularly, the issue of how beneficial FDI is fordeveloping countries forms the kernel of empirical controversy (Aitken \&Harrisson, 1999; Akinlo, 2004; De Mello, 1997; Haddad \& Harrison, 1993; Lipsey\&Sjoholm, 2004). In fact, different issues have emerged over the years, and these have led to various controversies in the post-war history of North-South relations includingthose connected with the impact of FDI in the industrialization of developing countries.

Nigeria, given her natural resource base and large market size, qualifies as a major recipient of FDI in Africa, and indeed, is one of the top three recipients of FDI in Africa, but the volume of FDI attracted so far has been mediocre compared with the resource base and potential need (Asiedu, 2012). The macroeconomic environment in Nigeria has not been conducive for the thriving of FDI, and no investor wants to invest in a place where he will suffer capital loss, no matter how promising and profitable it appears. 
The pattern of the FDI that does exist is often skewed towards the extractive industries (that is, the petroleum sector), so that it has been suggestedthat the differential rate of FDI inflow into Nigeria is because of natural resources, although the size of the local market may also be a consideration (Morriset 2000; Asiedu, 2002). Unfortunately, the efforts bymost countries in Africa, including Nigeria, to attract FDI to real sectors of the economy, such as the industrial and agricultural sectors, have not been encouraging. This development is disturbing and means there is little hope of economic growth and development for these countries.

There are good reasons for paying more attention toFDI. First, FDI can bring development capital without repayment commitments, and this is clearly differentfrom loan finance. Second, FDI is notmerely capital: it is an important and potent bundle of capital, contacts and managerial and technological knowledge, with potential spillover benefits for the host country's firms. Third, unlike other forms of capital flow, FDI has proved to be resilient during crises (Dadush, Dasgupta and Ratha, 2000; Lipsey 2001). This was evident in the Latin American debt crisis of the 1980s, the Mexican crisis of 1994-1995, and the Asian financial crisis of 1997-1998. These traits have encouraged intense competition for FDI amongdeveloping and transition economies. In spite of the tremendous benefits, the controversy still rages as to whether or not FDI constitutes a ladder to development. In the midst of these controversies the need arises to assess the impact of FDI flows and theattendant technologies of FDI forNigeria's manufacturing sector.

More importantly, FDI has been widely recognized as factors explaining economic growth. Past empirical studies (both cross-country and country-specific) into howFDIaffects growth (Karbasiet al., 2005; Kohpaiboon, 2004; Mansouri, 2005) and the FDI-growth nexus, promote economic growth and, by extension, improve manufacturing sector performance. Nevertheless, there are clear indications that the growth enhancing effects of FDIinflows vary from country to country. This means that there has been diverse and, sometimes, conflicting empirical evidence fromboth cross-country and country-specific analysis of the FDI-growth nexus.

The overall implications of the catalogue of problems identified above for Nigeria's manufacturing sector are unimaginable, unless something urgent is done. The researcher will be looking at the role of FDI in reversing this trend and channelling the sector towards economic growth and development. 


\subsection{The Flows of Foreign Direct Investment and Industrial Policy in the Nigerian Manufacturing Sector}

This section intends to review the flows of foreign direct investment into the Nigerian manufacturing sector and industrial policy in place at the different periods and more importantly, to further examine the flow of technological transfer into the sector and policies of the government in the area of research and development. This sub-heading will also examine the performance of the manufacturing sector with the inflowof foreign direct investment; with the emergence of trade liberalization policy and technological transfer in the Nigerian economy.

\subsubsection{The Performance of Nigeria Manufacturing Sector since Independence (1960)}

The manufacturing sector remains one of the vital sectors that can be employed to propel economic development in most of the developing countries including Nigeria. It acts as a catalyst in the transformation of the economic structure of countries, from simple, slow-growing and low value activities to more productive activities (Okonjo-Iweala and Osafo-Kwaako, 2007). As an engine of growth, a boost in manufacturing production offers prospect of economic growth, and with the availability of manufactured products, the speed of development can be enhanced. However, the output of the Nigerian manufacturing sector has been very sluggish over the years. This is particularly revealed when comparison is made with other sectors of the economy. Following this trend and structure associated with the Nigerian manufacturing sector, its impact in solving problem of poverty most especially is questioned. The Nigerian manufacturing sector has witnessed a series of fluctuations and unstable kind of growth and this has reflected in its share on Gross Domestic Product (GDP) and to the economy as shown in the Table 2-1 below. The problems associated with the manufacturing sector persisted, in spite of the efforts of the government in establishing the National Economic Empowerment Development Strategy (NEEDS), which emphasized the relevance of rising manufacturing sector performance. The history of industrial development and manufacturing in Nigeria is a classic illustration of a country's neglect of her agricultural sector and how this has denied many manufacturing firms and industries their primary source of raw materials.

There was a substantial growth experienced in the economy between the mid 70s and 80s; since then, the manufacturing sector has experienced a tremendous stagnation in output and for most of the period, it declined and the problems has become more pronounced since 1983. The problem in the manufacturing sector could be attributed to the fall in the global demand for oil output and its adverse effect on the price of oil. The fall in oil prices in 
the international oil market brought a fall in government revenue and consequently, foreign exchange earnings was badly affected forcing government to institute serious austerity measures. The manufacturing sector suffered from a precipitous reduction in rawmaterials and spare parts caused by these measures and these problems were translated into widespread industrial closures, massive retrenchment of the industrial work force and an extensive drop in capacity utilization from 71.5 percent in 1980 to 40.3percent and 36.1percent in 1990 and 2000 respectively before it appreciated in 2010 to 55.14percent (CBN bulletin, 2010). But it should be noted that there was never a time when the sector achieve 100percent in the capacity utilization; this has brought a serious set-back to the sector and further worsened its contribution to the country's total export, which fell from 42.7percent in the 1970 to 5.1 percent in 2010.This can further be explained with the table 2 below:

Table 2: Selected Indicators of Performance in the Nigerian Manufacturing Sector

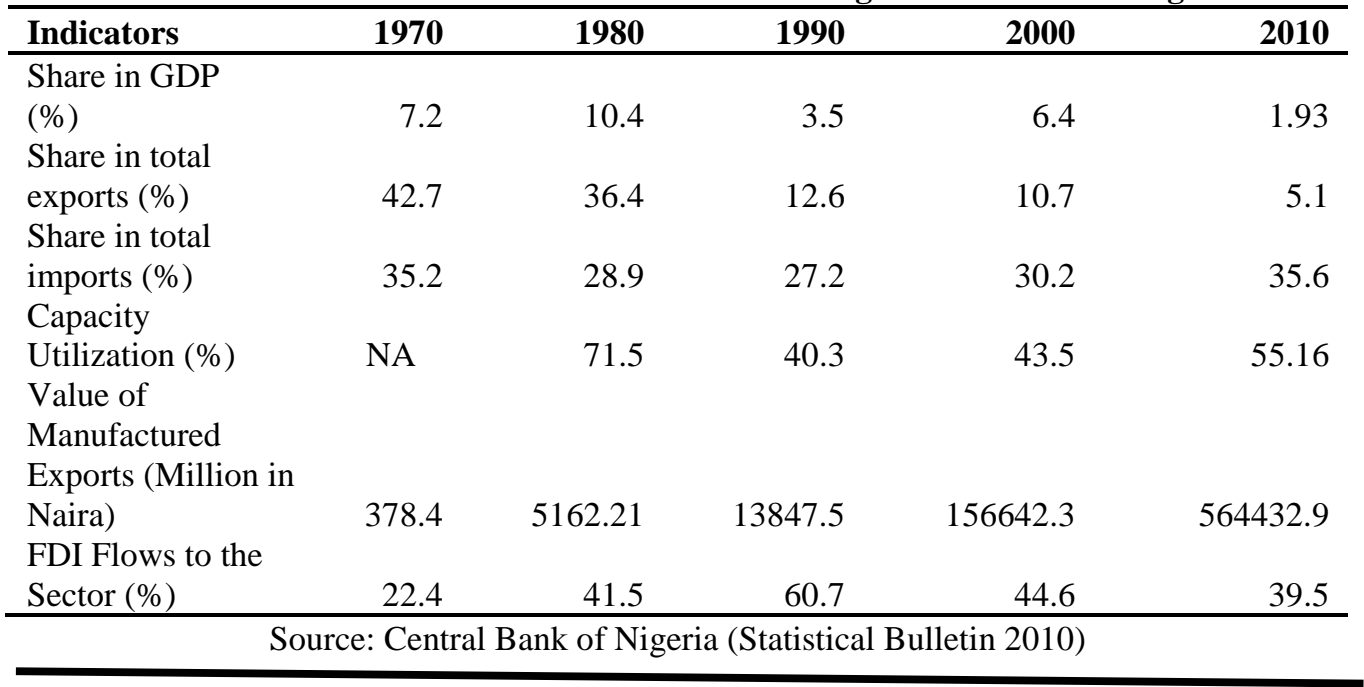

The share of the manufacturing sector in GDP as shown in the Table 2-1 rose from about 10.4 percent in 1980 as against 7.2 percent recorded for the sector in 1970, but fell to all time low of 5.1 percent in 2010. A number of factors accounted for this abysmal poor performance of the sector, chief among which could be traced to inadequate access to raw-materials and spare parts because of chronic foreign exchange shortage, that are required for importation of needed industrial inputs. The inadequate industrial inputs drastically affected industrial capacity utilization in the sector. The above illustration provided vital information in the manufacturing sector when the Structural Adjustment Programme (SAP) was initiated in 1986. The programme aimed at enhancing the performance of the sector, though a 
restructuring process was geared towards reducing import dependence and promoting manufacturing products for export. This was further appreciated in terms of the contribution of the sector to the country's total exports which was increased from about US378.4 million in 1970 to US564.5Billion in 2010.

To raise productivity in the sector, the Nigerian government laid much emphasis on manufacturing sector because it was envisaged that the modernization of the sector required a deliberate and sustained application and combination of sustainable technology management techniques and efficient system of mass production of goods and services (Malik, Teal and Baptist, 2006). Unfortunately, in spite of the recorded increase in the FDI inflows into the sector, the performance of the sector leaves much to be desired as general output, capacity utilization and sector contribution to GDP are still comparatively low. Also, the absence of locally sourced inputs as pointed by Adenikinju and Chete (2002) has resulted in low industrialization. It is quite evident that Nigeria's industrial performance has been disappointed in the last decade as the total manufacturing value added and exports have declined in relative terms (Alukoet al., 2004). The problems associated with the sector created a situation where Nigeria is losing its competitive edge and is becoming increasingly marginalized in the international industrial science due to unpredictable government policies resulting from dynamic inconsistency, macroeconomic instability, a distorting business environment, lack of basic raw materials, most of which are imported and weak industrial capabilities. Consequently, the trend in the performance of the industrial production cannot but indicate the falling productivity, which has serious implications for aggregate demand.

Presently, the Nigerian manufacturing sector is lagging behind other sectors in terms of productivity. The year 2010 brought some optimism by the growth recorded as shown in Table 2-1 above. The capacity utilization showed a slight improvement from 54.7 percent in 2009 to 55 percent in 2010. This development has been attributed to some policy initiatives aimed at improving the performance of some firms within the sub-sector. The policy initiatives include among others; granting of license for importation of quality raw materials for industrial use, provision of capital allowance, incentives for incurring excess capital expenditure, granting of input loan by the ministry of commerce and industry in collaboration with the Central Bank of Nigeria and commercial banks, provision of 2-3years duty free period for importation of machinery, equipment and spare parts during the phases of plant building and commencement of production, removal of restrictions on investments in system conversion by manufacturing firms (CBN bulletin, 2010). The important point here is that significant changes are yet to be recorded in the sector. This justifies the need for policy 
realignment potentially to help in building up indigenous manufacturing technological capacity in the country.

The introduction of Structural Adjustment Programme in 1986 and the emergence of a democratic government in 1999 provided opportunities in building a competitive economy through various policies such as the deregulation of various sectors among which is the manufacturing sector. This period witnessed greater Foreign Direct Investment inflows from the unimpressive flows of 22.4 percent in 1970 to the unprecedented flows of about 41.5 percent and 60.7 percent in 1980 and 1990 respectively, before experiencing a drop in 2010 to 39.5 percent (Table 2-1). It should be noted that another factor responsible for this remarkable flow in FDI to the sector, apart from the open economic policy regime, was the fact that the legal regime and its related institutions required for the creation of a market economy and sustainable investment climate were the priority of the public policy agenda of the new civilian regime.

\subsubsection{The Nigerian Manufacturing Sector and Industrial Policies from Independence to Structural Adjustment Period (1986)}

With the independence of Nigeria in 1960, trade policies have passed through various stages that have changed remarkably over time. The first stage of Nigeria's trade policies was characterized by the protectionist policies at independence in order to encourage industrial development that will be in line with the strategy of import substitution policy of that time. The second stage of the trade policy witnessed the era of the oil boom phenomenon occasioned by the attendant economic buoyancy and prosperity. This remarkable economic success propelled a relatively low tax trade policy regime of the 1970s. Lastly, the next stage witnessed a tough trade policy in response to the external balance position. This period was characterized by the massive economic downturn and balance of payment straits. The trade policies have in general become more restrictive in posture and this was evidenced by the compression of imports through qualitative barriers. These stages will further be elaborated.

The emergence of the indigenization policy initiated in 1972 was tagged "the Nigerian Enterprises Promotion Decree" (NEPD). The decree imposed several restrictions on FDI entry into the manufacturing sector. As a result, some 22 business activities were exclusively reserved for Nigerians, including advertising, gaming, electronic manufacturing, basic manufacturing etc. Foreign investment was permitted up to 60 percent ownership and provided that the proposed enterprise based on 1972 data, possesses share capital of US\$300,000 or turnover of US\$760,000. 
The objectives of the Nigerian Enterprises Promotion Decree of 1977 (which is the second indigenization policy) include

- Transfer ownership and control to Nigerians in respect of those enterprises formerly owned (wholly or partly) and controlled by foreigners;

- Foster widespread ownership of enterprises among Nigerians citizens;

- Create opportunities for Nigerian indigenous businessmen;

- Encourage foreign businessmen and investors to move from the unsophisticated spheres of the economy to domains where large investments are required.

The above decree tightened the restrictions on FDI entry in three ways: (a) by expanding the list of activities exclusively reserved for Nigerian investors such as bus services and film production, (b) by lowering permitted foreign participation in the FDI-restricted activities from 60 percent to 40 percent which included some manufacturing firms like processing firms and plastic and chemical manufacturing firms, (c) by creating a second list of activities, where foreign investments were permitted, was reduced from 100 percent to 60 percent ownership, including manufacturing of drugs, some metals, glass, hotels and oil services companies. A critical appraisal of the industrial development challenge of the 1970s shows that the hindrance was not located in the area of finance but in the dearth of human capital including techno-managerial capabilities and skills required for initiating, implementing and managing industrial projects (Oyelaran-Oyeyinka, 1997). This was further demonstrated by the fact that project preparation, feasibility studies, engineering drawings and designs including construction, erection and commissioning were contracted to foreign expatriates (Cheteet al. 2013).

The challenges of the 1980s necessitated the implementation of Structural Adjustment Programmes (SAPs) under the auspices of the World Bank and International Monetary Fund. This was due to the worsening in the balance of payment position of the country's economy resulting in the oil crisis, acute deterioration of the terms of trade and exacerbation of excess demand for imports originating from deficit financing of public expenditure, and an increase in public debts. The adjustment programme was aimed at diversifying the economic base, ensuring appropriate price and incomes policy, increasing efficiency, improving the policy environment for manufacturing and trade and restructuring of fiscal budgetary and expenditure (Chirwa and Zakeyo, 2003). The statistics in the table below support the thinking that the manufacturing sector in Nigeria performed relatively better during the import substitution and protectionist policy period (that is, the period 1960 to 1982), than during and after implementation of economic liberalization policies. 
Table 3: Trade Policies and Manufacturing Performance at Different Periods

\begin{tabular}{|c|c|c|}
\hline Period & Import Substitution Industrialization & $\begin{array}{c}\text { Average } \\
\text { manufacturing } \\
\text { growth } \\
\end{array}$ \\
\hline $1960-1982$ & $\begin{array}{l}\text { - } \\
\text { Overvalued Exchange rate System- } \\
\text { Fixed Peg } \\
\text { - } \quad \text { Non-tariff barriers to trade e.g. } \\
\text { import licensingand implicit foreign } \\
\text { exchange rationing } \\
\text { - } \quad \text { Active government involvement in } \\
\text { manufacturing industries } \\
\text { Low and Stable inflation and } \\
\text { interest rate } \\
\end{array}$ & 17.1 percent \\
\hline \multirow[t]{2}{*}{ 1983-1998 } & Structural Adjustment Period & $\begin{array}{c}\text { Average } \\
\text { manufacturing growth }\end{array}$ \\
\hline & $\begin{array}{l}\text { - } \\
\text { liberalization into manufacturing } \\
\text { sector } \\
\text { - } \\
\text { - } \\
\text { Bilateral trade agreements } \\
\text { Elimination of quantitative trade } \\
\text { restriction and exchange rationing } \\
\text { Privatisation of State-Owned } \\
\text { enterprises } \\
\text { - } \\
\text { Introduction of Export processing } \\
\text { zones } \\
\text { - } \quad \text { Liberalization of the financial sector } \\
\text { and interest rates } \\
\text { - } \quad \text { Period devaluation of the local } \\
\text { currency andliberalization of } \\
\text { interest rates }\end{array}$ & -3.69 percent \\
\hline $1999-2014$ & $\begin{array}{c}\text { Post-Structural Adjustment } \\
\text { /NEEDS Period }\end{array}$ & $\begin{array}{c}\text { Average } \\
\text { manufacturing growth }\end{array}$ \\
\hline & $\begin{array}{l}\text { - } \\
\text { Promotion of local value-added and } \\
\text { diversifying exports } \\
\text { - Imposition of high import tariffs on } \\
\text { finished goods } \\
\text { - Gradual Liberalization trade policy } \\
\text { regime } \\
\end{array}$ & 8.76 percent \\
\hline
\end{tabular}

Source: Average manufacturing growth represent the Average manufacturing growth rate, computed by authorized based on data from Central Bank of Nigeria statistical Bulletins

(Various Issues),extracted from the Central Bank of Nigeria Economic and Financial

Reviews (Various Issues).

\subsubsection{Manufacturing Sector and Post Structural Adjustment Programme Period}

There was a significant shift in trade policy direction towards greater liberalization as of 1986. This shift in policy direction was directly caused by the adoption of the structural adjustment programme (SAP). The programme 
was informed by the distortions in the economy, ushered in by the culture of controls, made it necessary for the government to put in place urgent and drastic steps to ameliorate the situation. Thus, in July 1986, the SAP was introduced to tackle the problem of imbalances in the economy and efficient allocation of resources. The main cardinal point of the programme includes;

i) Restructure and diversify the productive base of the economy in order to reduce the dependence on the oil sector and on imports;

ii) Ensuring fiscal and balance of payments viability overtime;

iii) To ensure strong foundation for the sustainable, non-inflationary growth; and

iv) Reducing the over-bearing influence of the unproductive investments in the public sector, enhancing the sector's efficiency and consolidating the growth potential of the private sector.

A number of strategic plans were outlined to realize the broad objectives of SAP. With respect to international trade, attention was directed to trade liberalization and the pricing system, with emphasis on the use of "appropriate price mechanism for the allocation of foreign exchange". The second-tier Foreign Exchange Market (SFEM) was then introduced, under which the rate of the country's domestic currency (Naira) was to be determined through the market forces of demand and supply. The price determination mechanism provided the means for ultimate allocation of foreign exchange to the end-users against the erstwhile use of administrative discretion. The application of import and export licensing became irrelevant and consequently abolished. In addition, to encourage export under the programme, the policy which required exporters to declare their export proceeds to the Central Bank of Nigeria $(\mathrm{CBN})$ was discarded. In effect, exporters were encouraged to retain 100 percent of their export earnings in their domiciliary accounts from which they could freely draw to meet their eligible foreign exchange transactions.

The implementation of the policy over the years has not impacted positively in the country's manufacturing sector. Looking at the manufacturing sector's performance during this period, it shows that the share of the manufacturing sector in the Gross Domestic Product (GDP has been relatively low. In 1970, it was about 9 percent, in 1980, it was about 10 percent, in 1990, about 8 percent and 1998, it was about 6 percent and in 2008, it was 5.9 percent (CBN Annual Report). Even though in the 1990s, particularly in 1994, manufacturing shares in GDP was about 7 percent, the growth rate was a negative of about 8 percent. Also at that same period, the overall manufacturing capacity utilization fell from over 70 percent in 1973 to 39 percent in 1986 and about 27 percent in 1998 (CBN Annual Report). It should be noted that only when firms are efficient that their potential for employment creation, enhancing technology adoption and ensuring equitable 
distribution of economic opportunities and macroeconomic stability can be attained (Inegbenebor, 1995).

\subsubsection{Manufacturing Sector and the Policy of National Economic Empowerment and Development Strategy (NEEDS) (From 1999 to 2014)}

Nigeria's trade and industrial policy regime as contained in the NEEDS has been directed to raise the level of competitiveness of domestic manufacturing firms, with a view to, inter alia, promoting local value-added raw-materials and encouraging as well as diversifying exports. The policy adopted under this programme was the gradual liberalization of trade regime. Thus, the government intends to liberalize the trade regime in such a way that the resultant domestic costs of adjustment do not outweigh the benefits. This is the fundamental basis on which to gauge the direction and implementation of the policy. To this end, the current reform packages are therefore formulated in such a way that it allows a certain level of protection of domestic industries. In concrete terms, the policy has translated into tariff escalation, with high effective rates in several sectors and lower import duties on raw-materials and intermediate goods that are not available locally. In addition, the impositions of high import duties on finished goods were the result of the policy perspective on the finished goods, which competed with local production.

\subsection{Literature and TheoreticalReviews of FDI}

A critical review of the theories of FDI illustrates the basic justification of cross-border investment. The existing literature suggests that for the last thirty years, FDI emerged much more ambitious in scope. In the 1960s, the effect of exportation of FDI had been the major issue, as evidenced by the Hymer-Kindleberger theory and Verom's (1966) in the product cycle theory. In the 1970s, however, the growth of the MNEs based on a theory of transaction cost formed the principal emphasis. By the 1980s, Dunning's eclectic approach had gained prominence. In the 1990s, the host country impact of FDI was subjected to empirical study and analysis.

\subsection{The Neo-Classical Theory}

Prior to 1960s, FDI and portfolio investment were considered as portfolio investment. When capital started to move across national boundaries, then capital movement came to be viewed separately from portfolio investment. The source-firm had to contend with differences in distance, time, markets, cultures, personnel, currency and host government, which were usually favourable to the local competitors. The theory of FDI had, therefore, to provide explanation why firms go against market elements 
to carry-out business in foreign markets and nations. FDI was originally believed to move from a country with low interest rate to those yielding higher interest rates. This is however an inadequate explanation in justifying investments across borders, since there had also been FDI transactions from higher interest (rates) countries to those with lower interest rates.

In 1960s, Hymer caused a major breakthrough in the theory of FDI. He came up with the industrial organisation perspective, which is often referred to as oligopolistic theory. He emphasized that the movement of capital in respect to FDI, is not associated with higher interest rates, but due to the financing international operations. Hence, market structure and competitive conditions are vital determinants of FDI flow. Firm-specific advantages and the firm's market position have been employed to provide explanation for the reason why MNEs engage in cross-border investments. These merits must be enough to outweigh the demerits confronted by the MNEs in competing with local firms.

Hymer concludes by asserting that international production has substantial negative impacts on the host economies, since it raises market barriers, increases concentration, limit the ability of the government to exact control over national economy, and may put at risk national productive and innovative products on the world demand. This is not that Hymer's theory disregard location advantages, but rather he treats it as exogenous factor related to the MNE's behaviour. Hymer's work spawned many other contributors in the theory of industrial organisation. The industrial theory of FDI was further extended by Caves $(1971,1974)$ and Kindleberger (1984). In their studies, they deviate from perfect competition as the factors that influences FDI, but placed more emphasis on the demerits of perfect competition in terms of geographical and cultural differences that the MNEs will face in their operation, when compared to domestic firms. For MNEs to be successfully embarked on FDI in a foreign country, they are required to possess some special ownership advantage over potential domestic competitors. The acquisition of technological advantage normally gives them some intangible rent yielding assets such as management skills and brands, which they believed to provide such advantages. This situation clearly, can be distinguished from portfolio management, which only includes crossborder flow of capital. It becomes imperative to state that FDI involves cross-border movement of different kind of resources in terms of product and process technology, management skills, marketing, distribution of technical skills, marketing distribution of technical skills and human capital. In clear terms, FDI includes a movement of intangible assets such as technological know-how across countries and inability to consider the technological skill can further underestimate the significance of FDI as an engine of growth for the recipient countries. But it should be noted that, the cost and benefits of 
such foreign capital in term of spillover effects have been largely ignored by the earliest theorists of FDI.

Another important theory so identified in literature in explaining the costs incurred by MNEs in the choice of locations and motives for international investment across national borders is the location theory provided by Buckley $(1985 ; 1990)$. The theory considered the supply (cost factors) and demand (market factor) variables influencing the spatial distribution of the production processes, research and development (R\&D) and the administrative functions of a firm. In respect to the host country, it was generally believed that the host country must obviously have some location-specific advantages such as lower wages, abundant raw materials, investment incentives, tariff and non-tariff protection, free trade zones, among others.

Furthermore, currency area has equally been introduced as an important dimension of the theory of FDI, as developed by Aliber (1970; 1971). He rejects arguments based on superior managerial skill because any of such superiority should take into account the costs and exchange rate. The implication is that some currencies are stronger compared with others, and firms operating in strong currency areas can compensate for the capital deficiency in weak currency areas through their own borrowings. This position was supported from the empirical observations that devaluation promotes FDI flow.

\subsection{The Internalisation Theory}

The origin of this theory was established in literature by Coase (1937) in his market failure, who argued that transaction costs on foreign activities make it more conducive for a firm to create an internal market as oppose to entering foreign markets. The idea has been further expanded by Buckley and Casson (1976). The internalisation theory proposed by Buckley and Casson (1976), investigate the choice between exporting and establishing a subsidiary in a major export locations. Expansion by FDI can be a viable alternative for a MNE, when it has an edge in term of competitive advantage over other firms. This firm-specific advantage needs to be safeguarded by the organisational structure, and by implication, it means that FDI becomes favourable when the benefits of internalisation outweigh its costs.

The impact of MNEs as an avenue for international diversification has been analyzed by Rugman (1979), who extended the internalisation theory and included FDI as a possible instrument. According to him, while internalisation is helpful in bringing about internal markets, bypassing capital market imperfection, it is also, at the core of the MNE concept, highly consistent with the transaction cost and eclectic theories. 


\subsection{Product Life Cycle Theory}

The major contributor to this theory was put forward by Vernon (1966). Vernon's (1966) study is anchored on the experience of the postsecond world war period and companies sequences involving domestic versus foreign production. In his model, FDI has been regarded as replacing trade. The product life cycle hypothesis states that based on the comparative advantage emanating from the pattern of factor endowments, a product invented in the home country initially enjoys competitive advantage in technology and inventory capabilities and serves the local markets.

At the next stage, a favourable combination of innovation and technological advantages makes the product an exportable commodity to countries where conditions are very similar to the home country. As the product gradually becomes standardized and labour becomes a significant input in terms of production cost, a foreign country location may become more attractive. The process could grow to such an extent that the home country could in itself be a recipient. Vernon (1979) reviewed his theory and opines that it had less power in elucidating the reasons for FDI. He combined the geographical reach of many firms and emphasized on gap reduction between the US and other national markets in respect to both size and factor cost. Although, current development could perhaps make various stages of product life cycle less applicable, it cannot be disputed that the theory remained valid in explaining the rational process leading to FDI.

It needs to be emphasized at this junction that the product life cycle theory has been subjected to various modifications, so that recent changes in the FDI theory could be accommodated. Grosse and Kujawa, (1995) opines that product life cycle is a dynamic view of investigating the rationale for trade flows in the context of changing technology and multiple markets. They allied with Vernon's view that the export market, which forms the nucleus for FDI is the third stage of the product's life cycle, is important and low cost advantage is the significant consideration at this stage of decision making.

\subsection{The Eclectic Approach}

Dunning $(1977 ; 1979 ; 1993$ 1997) developed the eclectic theory by synthesizing the current theories of FDI to identify and analysis the important factors influencing FDI. FDI location will therefore depend on three sets of factors:

(i) Ownership (O): the "O" advantages include marketing skills and $\mathrm{R} \& \mathrm{D}$ skills or production skills that enable firms to provide goods and services more competitively in their countries and in other countries.

(ii) Location (L): this includes low-cost labour, incentives to production on the part of the host government, natural resources, domestic market 
potentials, and political stability. These are not easily transferable between countries and could differ from the home country situation. Ownership advantages tends to provide answer on why some firms, but not others go abroad, and provide an explanation that a successful MNE possess some firm-specific advantages which allows it to overcome the costs of operating in a foreign country. An important idea is the fact that firms are in control of collection of assets and that these assets can be employed in production at different locations without reducing their effectiveness. Example includes product development, managerial structures, patents and marketing skills, all of which are encompassed by the catch-all term of Helpman (1984) "headquater services".

It should be noted that international trade theory has tended to take ownership advantages for granted; rather, more attention has been devoted to exploring alternative motives for MNEs to locate abroad. An important issue that motivated much attention is the distinction between "horizontal" and "vertical" FDI. Horizontal FDI occurs when a firm locates a plant abroad in order to improve its market access to foreign consumers. In this case, a firm tries to replicate its domestic production facilities at a foreign location. While in the case of vertical FDI, FDI is not primarily or even necessarily aimed at production for sale at foreign market, but rather seeks to avail itself of lower production costs there since in almost all cases the parent firm retains its headquarter in the home country, and the firm-specific or ownership advantages can be seen as generating a flow of "headquarter services" to the host-country plant, this explains why all FDI is vertical in nature.

(iii) International (I): the "O" and "L"must be complimented by internalisation to overcome transaction costs, such as those pertaining to transport, information, different taxes and tariffs (which differ among countries), and other market imperfections. It should be noted that OLI does not directly address one of the important issues that dominated economists thinking about FDI, the distinction between horizontal and vertical motives for locating production facilities in foreign countries nor does it address the increasingly important distinction between Greenfield and M\&A modes of engaging in FDI. Nevertheless, it remains a helpful way of organising thinking about one of the most significant features of the world economy.

\subsection{Macroeconomic Theory}

This theory could be considered as a milestone in the theory of FDI. It was introduced by Kojima (1973; 1984). The theories earlier discussed were predominantly designed for US firms investing abroad, differentiating them from Japanese FDI. The latter are primarily trade oriented and in line with dictates of the principle of comparative advantage. In contrast, US activity was mainly an oligopolistic market structure. There was less 
emphasizes on trade and activity was directed on firm-specific profit orientation. Kojima's approach predicted that export-oriented FDI occurred in countries with a comparative advantage for the host country. Thus, when exports grow FDI is characterized as welfare-improving and trade-creating. Due to Kojima's preference for Japanese style management, his approach has been considered to be biased and inadequate. Dunning (1988), for instance, pointed out that Kojima's neo-classical framework was inadequate in capturing the impact of firm-specific advantage in determining FDI flow. He further argued that Kojima's theory is grossly inadequate in explaining modern trade; it could not, for instance, provide adequate reason for trade flows, which are based less on the distribution of factor endowments, and more on the need to exploit the economies of scale, product differentiation and other manifestations of market failure (Dunning, 1993).

\subsection{Empirical Reviews}

Adejumo, (2013), in his the study investigates the relationship between FDI and the value-added to the manufacturing sector in Nigeria. The study employs the autoregressive lag distribution technique to examine the relationship between foreign direct investments and manufacturing value added, it was established that in the long run, FDI have a negative effect on the manufacturing sub-sector in Nigeria. He however, argues that the presence of multinationals in the host economy should be able to influence the private investment on their economy. Besides, these investments should be channeled to other sectors where comparative advantage exists, so as not to erode the capability or the wherewithal of nationals. He concluded that foreign private investment should complement the production efforts of the labour force in the host country, in term of skills, technical know-how and wages.

Alvarez (2003) the study analysis the panel data from more than 7000 firms in the manufacturing industry for the period 1990-1996 in Chile. He observed that MNEs' affiliates present much higher levels of productivity than do local firms. He further argues that FDI does positively impact on the level of productivity. Nevertheless, the effects seem to be small in magnitude. The small effect of FDI on the manufacturing may be attributed to the low number of foreign firms operating in the industry, suggesting that a bigger number of foreign firms may be necessary to bring about significant impact on local firms. He also emphasizes that most of FDI inflows have been directed to the mining and services industries.

Oscar and Simon (1994) investigate the inflow of FDI into Spanish economy during the period 1964 to 1989 and using autoregressive distributive lag technique, the study established a long-run relationship between FDI and GDP, inflation, trade barriers and capital stock. 
In analyzing the macroeconomic impact of FDI on China for 19791993, Sun (1996) found that FDI contributed positively to Chinese domestic capital formation, industrial growth, exports and employment creation. With the data limitation faced by the study, he pooled cross-section and time series data at the provincial level and formulated a regression model to test the hypothesis. Sun (1996), applied the Generalized Least Squares (GLS) method and the study establish that FDI had significantly contributed to the economic development of China. The impact of FDI was seen as the main contribution it had to domestic capital formation, promotion of industrial production, exports and the creation of new employment. Sun (1996) further stated that FDI contributed to financial and physical capital development and encourages local investment.

Ekanayake et al. (2003) demonstrate the relationship between output level, inward FDI and export across the developed and developing countries (Brazil, Canada, Chile, Mexico and U.S) from 1960 to 2001 by using the granger causality test. The results of the research are not consistent across these countries. Importantly, a two-way causal relationship between inward FDI and exports is found in the U.S and Canada and the existence of a oneway, moving from inward FDI to export is established in Brazil, Chile and Mexico.

\subsection{Theoretical Model}

The model to investigate the study i.e the impact of FDI flows on manufacturing GDPm can be shown thus:

$$
G D P_{m}=f\left(F D I, E X R, E X P_{m}, C P I\right) \quad E q 1
$$

Where $\mathrm{GDP}_{\mathrm{M}}=$ Manufacturing sector output

FDI $=$ Foreign direct investment

$\mathrm{EXR}=$ Real exchange rate

EXPm $=$ Value of real export

$\mathrm{CPI}=$ Consumer price index

The above implicit function in the model in equation (Eq 1), can further be reduced to a linear functional form expect CPI that remain in its actual figures and can be shown thus:

$$
\begin{aligned}
\ln G D P_{M}=\alpha & +\beta_{1} \ln F D I+\beta_{2} \ln E X R+\beta_{3} \ln E X P_{m} \quad \text { Eq } 2 \\
& +\beta_{4} C P I+\mu_{t}
\end{aligned}
$$


Apart from the linear regression that will be estimated above, the study will further employed Variance decomposition and Impulse Response functions in the analyses of the study.

\subsection{Variance decomposition}

Generally, VARs becomes over-parameterised with the inclusion of many lags on the right-hand side of the equation, which makes short-run forecasting difficult to achieve. To overcome this situation and understand the relationship among the variables it is common to analyse the properties of the of the forecast error. In order to gauge the relative strength of the variables and transmission mechanism response, the system will be shocked and partitioned the forecast error variance decompositions (FEVDs) for each variable in the system. By partitioning, the variance decomposition attributable to innovations in other variables in the system can provide an indication of these relativities (Masih, 1995). The vector error correction model does not provide any indication of the dynamic properties of the system and also does not allow people to gauge the relative strength of the Granger causality or degree of exogeneity among variables (Masih, 1995).

The variance decomposition analysis provides useful information about the relative importance of each innovation in influencing the variables in the system. This means that it is possible to separate the proportion of the movements in a sequence due to its shocks and other variables' shocks. We can obtain the variance decomposition using the same Vector Moving Average (VMA) representation that was previously obtained in Eq 3, if we forecast $\mathrm{y}_{\mathrm{t}+\eta} \eta$ periods ahead, the ahead forecast error will be

$$
\mathrm{y}_{\mathrm{t}+\mathrm{\eta}}=\mu+\sum_{\boldsymbol{i}=\mathbf{0}}^{\infty} \quad \phi_{\mathrm{i}} \varepsilon_{\mathrm{t}+\mathrm{\eta}-\mathrm{i}}
$$

\section{Eq 3}

The $\eta$-period forecast error is equal to the difference between the realisation of $\mathrm{y}_{\mathrm{t}+\mathrm{n}}$ and its conditional expectation:

$\mathrm{y}_{\mathrm{t}+\mathrm{\eta}}-E\left(y_{\mathrm{t}+\mathrm{\eta}}\right)=\sum_{i=0}^{n-1} \quad \phi_{\mathrm{i}} \varepsilon_{\mathrm{t}+\mathrm{\eta}-\mathrm{i}}$

\section{Eq4}

The variance of the $n$-step ahead forecast error, denoted as $\partial_{\mathrm{yt}}(\eta)^{2}$, for each variable in the vector $\mathrm{y}_{\mathrm{t}}=\left(\mathrm{y}_{\mathrm{it}}, \mathrm{y}_{2 t} \ldots . . . \mathrm{y}_{\mathrm{n}}\right)$ is equal to $\partial_{\mathrm{yt}}(\eta)^{2}=\partial^{2}$ yit $\left(\sum_{i=0}^{n-1} \quad \phi_{\mathrm{i}}^{2}\right)+\partial_{\mathrm{y} 2 \mathrm{t}}^{2}\left(\sum_{i=0}^{n-1} \quad \phi_{\mathrm{I}}^{2}\right)+\ldots . .+\partial^{2}{ }_{\mathrm{y \eta t}}\left(\sum_{i=0}^{n-1} \quad \phi_{\mathrm{i}}^{2}\right)$

Eq5

Fromthis expression it is possible to decompose the variance of the forecast error and isolate the difficult shocks; particularly we can separate the different proportion of the variance due to shocks in the sequence $\left\{\varepsilon_{y t}\right\}$. For example, in the case of having only two variables, $\left(y_{i t}\right.$ and $\left.y_{2 t}\right)$, the variance decomposition of the forecast error of $y_{i t}$ can be found by dividing equation Eq 5. In this way we can get the proportion of $\sigma_{y t}(\eta)^{2}$ due to movements in its $\left\{\varepsilon_{y i t}\right\}$ and $\left\{\varepsilon_{y 2 t}\right\}$. 


$$
\begin{aligned}
& 1=\partial^{2}{ }_{\mathrm{yit}}\left(\phi_{11}(0)^{2} \ldots \ldots \phi_{11}(\eta-1)^{2}\right. \\
& \partial \mathrm{y}_{\mathrm{it}}(\eta)^{2}
\end{aligned}
$$

It is usual that $\varepsilon_{\mathrm{t}}$ shocks to a specific variable will explain most of its own forecast error variance, especially at short horizons. Eventfully, this proportion tends to decrease.

\subsection{Impulse Response Function}

On important aspect of dynamic multivariate system is that provided they are mathematically stable-they can be used for dynamic policy simulation. The impulse-response functions are important tools that portray the expected path over time of the variables to shocks in the innovations; these functions indicate which variables function have been used to distinguish temporal from permanent shocks (Bayoumi and Eochengreen, 1994). In our case they will be used to determine the extent to which every endogenous variable reacts to an innovation of each variable.

The impulse response functions are generated by a Vector Moving Average (VMA), a representation of a VAR in standard form in terms of current and past values of the innovations (et). We derive the VMA from equation (5), assuming there is only one lag and no constant term:

$$
y_{t}=\Pi_{0}+\Pi_{1} y_{t-1}+\varepsilon_{\mathrm{t}}
$$

\section{Eq6}

$\mathrm{II}_{1}$ is a matrix of coefficients from the reduced form and $\mathrm{II}_{0}$ is a vector of constants. Lagging this system one period and substituting for yt1 :

$$
\begin{array}{r}
y_{t}=\Pi_{0}+\Pi_{1}\left(\Pi_{0}+\Pi_{1} y_{t-2}+\varepsilon_{\mathrm{t}-1}\right)+\varepsilon_{\mathrm{t}} \\
=\left(I+\Pi_{1}\right) \Pi_{0}+\Pi^{2}{ }_{1} y_{t-2}+\Pi_{1} \varepsilon_{\mathrm{t}-1}+\varepsilon_{\mathrm{t}}
\end{array}
$$

If we keep on substituting $\mathrm{n}$ times, eventually we get the following expression:

$$
y=\left(1+\Pi_{1}+\ldots+\Pi_{1}{ }^{\mathrm{\eta}}\right) \Pi_{0}+\Pi_{1}{ }^{\mathrm{n}+1} y_{t-\eta+1}+\sum_{i=\mathbf{0}}^{n} \quad \Pi^{\mathrm{i}}{ }_{1} \varepsilon_{\mathrm{t}-\mathrm{I}}
$$

\section{Eq 8}

If we assume that there is stability in the model ( the characteristics roots of $\Pi$ have modulus less than one) then in the $\operatorname{limit} \lim \Pi_{i}^{n_{i}}=0$ holds, under these conditions we end up expressing yt, as a process generated by an infinite sum of lagged random errors weighted by diminishing coefficients plus a mean u"

$$
y_{t}=\mu+\sum_{i=0}^{\infty} \quad \Pi^{\mathrm{i}}{ }_{\mathrm{i}} \varepsilon_{\mathrm{t}-1}
$$

Eq 9

This is known as a VMA representation and from this, it is possible to trace out the time path of different shocks to the variables in the VAR. using the lag operator, the VMA is equal to:

$$
y_{t}=\mu+\Psi(L) \in_{\mathrm{t}}
$$


Matrix $\Psi$ contains the impulse-response functions; a coefficient in $\Psi$ will describe the response of an endogenous variable yt at time $t+s$ to a one unit change in the innovation $\in \mathrm{jt}$, ceteris paribus. Or:

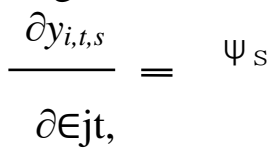

\section{Eq11}

s refers to the period. so we have that each coefficient measures the response of the modeled series to shocks in the innovations. Depending on the number of periods used in the equations, the impulse response functions will show the time path due to shocks in the error terms. If the stability condition is satisfied, the response of a variable to a shock in the system will move it away from the its equilibrium but eventually will tend to return to it. The speed of adjustment will depend of the influence of each shock in the variable.

Unfortunately the residuals in the VAR are correlated and the model is under identified; for this reason it is necessary to apply a transformation to the innovation so that they become uncorrelated. One way is by transforming the VAR in a model where the errors are not contemporaneously correlated; this can be done through the orthogonalisation of the innovations (Charemza and Deadman, 1997). Another way-which is used in this study, is the Cholesky decomposition. This is a matrix decomposition of a symmetric matrix into a lower triangular matrix and its transpose. In this case, using the residual covariance matrix (' $\Omega$ ) as the symmetric matrix, we can decompose it into"

$$
\Omega=\mathrm{PP}^{\mathrm{T}} \text { where } \mathrm{P}=\mathrm{AD}^{1 / 2}
$$

\section{Eq12}

A is a lower triangular matrix with 1 's along the principal diagonal and $D$ is a unique diagonal matrix whose $(j, j)$ element is the standard deviation of the residual $\mathrm{j}$. $\mathrm{P}$ is a lower triangular matrix. Using matrix $\mathrm{A}$, we can express $v_{t}$ as a vector of uncorrelated residuals $v_{t}=P^{-1} \in_{t}$. The reason is that $\mathrm{D}$ is a diagonal matrix that contains only uncorrelated elements. Every column in $\mathrm{P}$ (denoted as $\mathrm{p}_{\mathrm{j}}$ ) will capture how the forecast of all innovations changes as a result of new information (besides the information contained in the system). If we incorporate this component in (Eq 11) we get:

$$
\partial y_{j t} \quad=\psi_{\mathrm{s}} P_{\mathrm{j}} \quad \underline{\partial y_{t+\mathrm{s}}}
$$

\section{Eq13}

Each coefficient in the expression above will describe the response of the endogenous variable to a unit change in the innovations over time. 


\subsection{Description and Sources of the Data}

MFDI is the flow of foreign capital investment into the manufacturing sector. The foreign capital can theoretically expedite the process of industrial development as well as manufacturing sub-sector in poor countries by providing industry, capital, infrastructure, employment, international market access, revenue and technology (Lipsey, 2001; Ratha, 2005). The data is sourced from Central Bank of Nigeria.

GDPm is the value of the manufactured goods contributed to the gross domestic product. The data is sourced from National Bureau of Statistics.

CPI represents Consumer Price Index and it measures inflation in the country and one of the classic symptoms of loss of fiscal or monetary control is unbridled inflation (Nonnemberg and Mendoca, 2004). Therefore it is used to capture the overall macroeconomic stability of the country and since investors prefer to invest in more stable economies that reflect a lesser degree of uncertainty. The data is sourced from UNCTAD statistical year book published by United Nations on trade and development.

EXR represents Exchange rate and are expected to negatively affect GDPm. This is so because they affect a firm's cash flow, expected profitability and consequently its contribution to the GDP of the manufacturing sector. Exchange rate flunciations are as measure of macroeconomic instability, the higher and more unstable it is, the less contribution to GDPm (ErdalTatoglu, 2002; Maniam, 1998). The data for nominal exchange rate are sourced from National Bureau of Statistics and stated in real form.

Error term $\mu$ : the error term represents uncontrolled country specific factors such as demand shocks, business cycle, labour market wages as well as conflicts, international business situation as well as measurement error in the dependent variable and omitted explanatory variables. The error term is assumed to be independently and identically distributed.

EXPm represents manufacturing exports and this is the volume of manufacturing exports and affects the GDPm positively. The export is capable of reducing the country's balance of payment disequilibrium. The positive effect on GDPm is hypothesized. The data for manufacturing exports are sourced from Central Bank of Nigeria Statistical Bulletin of various issues up to 2013 edition. 


\subsection{Analysis and Results of the Study}

\section{Table 4: Ordinary Least Square}

Duration: For the entire Period

Dependent Variable: LGDPm

Method: Least Square

Date: 09/20/15

Sample

19802013

Included Observation: 34

\begin{tabular}{|c|c|c|c|c|c|}
\hline Variable & Coefficient & Std.Error & t-statis & & Prob. \\
\hline $\mathrm{C}$ & 9764.548 & 9584.22 & 1.01888 & & 0.3167 \\
\hline LMFDI & 0.87085 & 0.19852 & 4.38668 & & 0.0001 \\
\hline LCPI & 1306.306 & 214.037 & 6.10325 & & 0 \\
\hline LEXR & -70.0714 & 130.639 & -0.5365 & & 0.5958 \\
\hline LEXPm & 0.466698 & 0.12712 & 3.67156 & & 0.001 \\
\hline $\begin{array}{l}\text { R-Squared } \\
\text { Adjusted R- }\end{array}$ & 0.987391 & Mean Dependent Var. & & 208711.6 & \\
\hline Squared & 0.985652 & S.D Dependent Var & & 241476.2 & \\
\hline S.E of regression & 28925.07 & Akaike Inf. Criterion & & 23.51786 & \\
\hline $\begin{array}{l}\text { Sum Squared } \\
\text { resid }\end{array}$ & $2.43 \mathrm{E}+10$ & Schwarz Inf. Criterion & & 23.74232 & \\
\hline Log Likelihood & -394.804 & Hannan-Quinn & & 23.59441 & \\
\hline F-Statistic & 567.7317 & Durbin Watson & & 1.101801 & \\
\hline Prob. F-Statistic & 0 & & & & \\
\hline
\end{tabular}

VAR Granger Causality/Block Exogeneity Wald Tests (For the entire Period)

\begin{tabular}{|c|c|c|c|c|c|}
\hline & \multicolumn{5}{|c|}{ Dependent Variable } \\
\hline & $\Delta($ GDPm) & $\Delta(\mathrm{CPI})$ & $\Delta(\mathbf{E X P m})$ & $\Delta(\mathbf{E X R})$ & $\Delta$ (MFDI) \\
\hline$\Delta(\mathrm{CPI})$ & $37.7(0.00) * * *$ & - & $5.74(0.06)^{*}$ & $0.35(0.553)$ & $\begin{array}{c}16.07(0.00) * \\
* *\end{array}$ \\
\hline$\Delta(\mathbf{E X P m})$ & $13.84(0.00)^{* * *}$ & $6.96(0.31)$ & - & $7.60(0.02)^{* *}$ & $\begin{array}{c}93.97(0.00) * \\
* *\end{array}$ \\
\hline$\Delta(\mathbf{E X R})$ & $4.26(0.12)$ & $1.97(0.37)$ & $7.60(0.02)^{* *}$ & - & $0.103(0.748)$ \\
\hline$\Delta($ MFDI) & $12.087(0.042)^{* *}$ & $\begin{array}{c}6.76(0.03) * \\
*\end{array}$ & $0.18(0.076)$ & $2.8(0.930)$ & - \\
\hline$\Delta($ GDPm) & - & $\begin{array}{c}8.29(0.02) * \\
*\end{array}$ & $0.96(0.757)$ & $0.18(0.670)$ & $0.97(0.325)$ \\
\hline
\end{tabular}

The VAR result was based on 3 year lag structure and $* * *, * *, *$ indicates statistically significance at 1 percent, 5 percent and 10 percent levels respectively. Figures in parenthesis

() are P-value

In entire period, the regression result of the model shows that RSquared (Adjusted) is 98 percent, indicating that the co-efficient of 
determination of the model of 98 percent of variation in the dependent variable is explained by the independent variables in the model. More so, the F-statistic of the model is 0.0000 , which is quite significant at 1 percent level. This implies that the model ascertain the overall significant of the independent variables used in the model.

The regression of the model shows that LMFDI exact a positive influence on the LGDPm and the influence is statistically significant. This indicates that one percent rise in MFDI, will lead to 87 percent increase in the GDPm. This tends to confirm the effectiveness of economic policy by adopting a liberalized industrial and trade policy regime. The policy was undertaken with a view to improve efficiency and productivity as well as to improve the competitiveness of Nigerian industries. The policy makers in Nigeria have undertaken series of measures in the past to attract foreign investment to the manufacturing sector in the country. The result of the measures put in place to attract investments into the sector in the past years, confirm that foreign direct flows into the sector have increased in ten-fold. But initially, the flows of the foreign investment were directed to petroleum sector and this account for its insignificant performance to Manufacturing Gross domestic product, but as the industrial and trade policies adopted by the government take firm root, attentions are given to the manufacturing sector in terms of flows of foreign direct investment.

Furthermore, the regression result also shows that exports of manufactured goods exact positive influence on Manufacturing Gross domestic product and it is even statistically significant in long run. This result shows that one percent rise in EXPm will lead to 46.7 percent increase in GDPm. This result confirms that the presence of MNEs with attendance foreign capital inflow, this has altered the exports behavior of Nigerian domestic firms in the area product and process innovation. This implies that foreign direct investment into the sector have helped to improve local manufacturing firms to produce goods not only to meet local market demands but also to seek for the expansion in the export markets. This result was confirmed in a study carried out by Rettab, Rao and Charif (2009), where it was recognized with substantive evidence that a firm's openness to the external economy does positively affect innovative intensity. This can be explained by the fact that expanding capacity to produce for the external economies keeps the firms abreast of the latest developments, current production trends, greater capacity to meet growing customer requirements as well as maintaining the competitive edge in the sector.

In addition, the exchange rate impact negatively on Manufacturing Gross domestic product and it is conformity with expected sign. This result tends to confirm the import dependency status of the country. The result of the analysis shows that coefficient of exchange rate is observed to be 
negative. This result tends to suggest that there is an inherent inverse relationship between exchange rate and Manufacturing Gross domestic product. This result is however contrary to the theoretical expectation that depreciation will promote manufacturing exports, encouraging local use of inputs and promote growth in the manufacturing sector. Based on the findings of this study, it can be concluded that the exchange rate management policy in Nigeria, which presently directed towards exchange rate depreciation has not contributed significantly to the growth of the manufacturing sector. This result further conform with the past study carried out by Ubok-Udom (1999), where the study examine the relationship between currency depreciation and domestic output growth in Nigeria.

The consumer price index (LCPI) was positively influenced the Manufacturing Gross domestic product and statistically significant at 1 percent level during the period before the crisis. This result is however contrary to economic expectation, which is in fact negative. This situation can be attributed to high inflationary rate experience in the economy and it should be noted that from the theoretical literatures, it is generally accepted that the phenomenon of high inflation in an economy has an undesirable effects and particularly on the stability of prices of goods and services. For this reason, stakeholders in the economy which include regulatory agencies and policy makers are concerned about the costs and effects of high inflation. It becomes imperative for Gokal and Hanif (2004), where they argued that inflation may also reduce a country's international competitiveness by making its exports relatively more expensive, thus impacting on the balance of payments position.

The entire period regression's result is also confirmed by the VAR Granger causality result in the table 5 below. The VAR Granger causality shows that the MFDI in the Lag 1 to 3 jointly

GDPm, but GDPm do not cause MFDI. This result shows the significant influence of MFDI on the GDPm at the both pre and post crisis periods and this confirms a unidirectional causality that runs from MFDI to GDPm.

Furthermore, CPI causes GDPm, while GDPm also causes CPI and hence, the result detects a bi-directional causality between GDPm and CPI. A rise in inflation rate in the country can increase the level of productivity.

Nominal exchange rate (EXR) do causes not GDPm, but GDPm do causes EXR and hence, there is a unidirectional causality that running from GDPm to EXR. By implication, to ensure a fall in exchange rate, manufacturing sector output must be increased, so as to reduce imported manufactured goods.

Lastly, manufacturing export (EXPm) do causes GDPm, but GDPm do not causes EXPm. This result shows a unidirectional causality that runs 
from EXPm to the GDPm. The result confirms the need to raise the volume of exports, in order to increase the GDPm.

Most of the scholars are skeptical about the statistical efficiency of the coefficient estimates from VECM; hence, most of them are comfortable with the variance decomposition and impulse response as better way of analyzing the contribution of policy variables to target variables in macroeconomic model. This approach is followed in this study to analyze the relative contribution of the variables in the model. As in any standard VAR model analysis, the way the variables entered the model is extremely significant for the interpretation of the results. Therefore, in this objective, the policy variable is placed first followed by the variables. This is based on the economic intuition that the policy variables influence the target contemporaneously. While the target variables influence the target variables are "less" endogenous than the policy variables (Akinlo, 2003).

Hence, the variance decompositions are applied here to gauge the strength of the causal relationship among all variables in the system. This dynamic analysis beyond the sample strengthened the empirical evidence from the earlier granger causality analysis that has been done earlier. Table 5-20 below shows the variance decompositions of the forecast error variances in the system up to 20years.

\subsection{Generalized Variance Decomposition (VDCs) results}

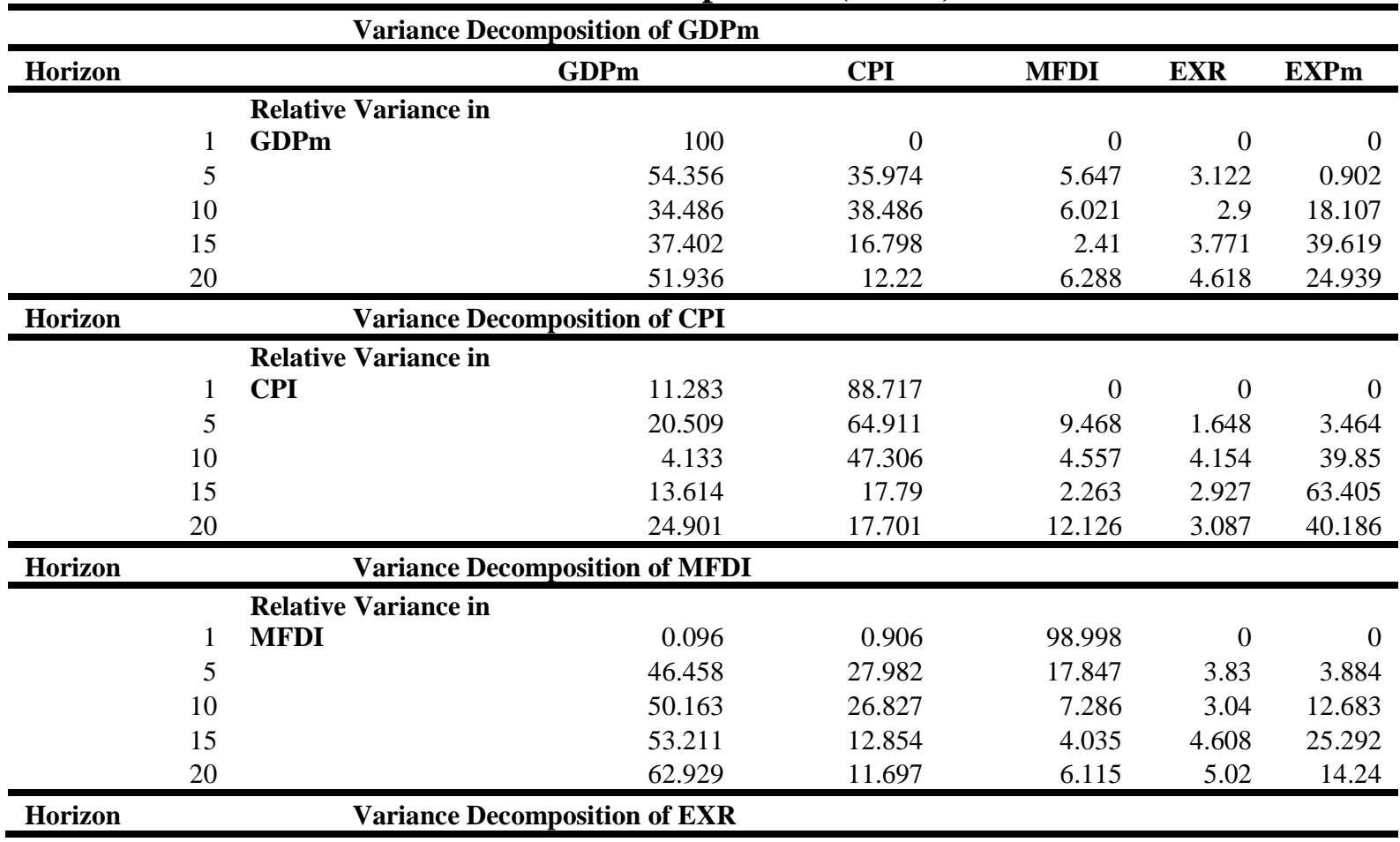




\begin{tabular}{|c|c|c|c|c|c|c|}
\hline & Relative Variance in & & & & & \\
\hline 1 & EXR & 11.968 & 14.947 & 2.424 & 70.662 & 0 \\
\hline 5 & & 52.563 & 9.666 & 3.042 & 34.684 & 0.046 \\
\hline 10 & & 54.734 & 7.834 & 3.079 & 23.599 & 10.754 \\
\hline 15 & & 60.371 & 8.992 & 4.041 & 9.707 & 16.888 \\
\hline 20 & & 58.879 & 14.637 & 10.553 & 5.363 & 10.568 \\
\hline \multirow[t]{7}{*}{ Horizon } & Variance De & of EXP & & & & \\
\hline & Relative Variance in & & & & & \\
\hline & EXPm & 11.191 & 1.062 & 5.889 & 7.031 & 74.827 \\
\hline & & 16.34 & 22.865 & 19.632 & 1.948 & 39.155 \\
\hline & & 12.458 & 45.361 & 13.252 & 7.233 & 21.696 \\
\hline & & 12.424 & 29.88 & 3.699 & 6.748 & 47.631 \\
\hline & & 15.067 & 14.429 & 8.137 & 2.748 & 59.62 \\
\hline
\end{tabular}

The results of the variance decomposition reveal that the forecast errors in each variable that can be attributed to innovations in other variables over twenty year periods. The forecast error variance of LGDPm in the system is largely attributable to its own innovation, although overtime the innovations of other variables show a tendency to increase gradually. Forecast error variance decompositions are presented in table, which help to identify the main channels of influence for the individual variables. The numbers under each variable represent the percentage of variance of the variable analyzed that was attributable to particular variable over a 20year periods and the result of variance decompositions can be summarized as follows:

The variance decomposition results (table 6) shows that the variance of manufacturing gross domestic product (GDPm) growth rate is always caused by 100 percent by itself in the first year. The fluctuation in GDPm in both the short-run and long-run are explained by its own shock approximately 54 percent in the 5period and only to fall to 51.9 percent in the 20 period. The shocks attributable to manufacturing exports (EXPm) are predominant, able to explain 24.9 percent of GDPm variability in the longrun. Also in the long-run, Consumer price index (CPI) will able to explain 12 percent of fluctuation in the GDPm. While other variables like manufacturing foreign direct investment (MFDI) and Exchange rate (EXR) have small and trivial effect.

The variability of exchange rate (EXR) in the short-run of 5 periods was 34.6 and continues to fall even in the long-run to 5.3 percent in the 20 periods. The GDPm shocks have dominant effect in keeping fluctuations in the exchange rate at 58 percent. The shocks to CPI can explain approximately 14.6 percent of long-run variability in exchange rate. The effects of shocks attributable to MFDI and EXPm are small and they are in the region of 10.5 percent each respectively in provoking a long-run fluctuation in the exchange rate. 
Consumer price index (CPI) in the short-run explained largely by its own shock, however, in the long-run, its effects will decrease. In the longrun, shocks to manufacturing exports (EXPm) and Manufacturing gross domestic product (GDPm) are predominantly able to explain 40 percent and 24 percent respectively of CPI variability. The shocks to MFDI are significantly able to explain 12 percent of fluctuations in the price level. While the shocks to exchange rate have are small and trivial effects on price level.

The variability of manufacturing exports (EXPm) in the short-run and long-run are associated mainly with its own shock, 74.8 percent and 59.6 percent in the both short-run and long-run respectively. The exchange rate shocks and shocks attributable to MFDI are just 27 percent 8.1 percent of long-run fluctuation in manufacturing exports. The shocks of CPI shocks to GDPm are in the region of 14.4 percent and 15 percent respectively.

In the case of MFDI, the variability of MFDI in the short-run is associated mainly with its own shock and the shocks are very significant. The effects of its own shock in the long-run are very small to the region of only 6 percent. The shocks attributable to GDPm are very significant in the long-run to cause fluctuations in the MFDI with 58.8 percent. The shocks attributable to CPI are also high, able to explain 14.6 percent of fluctuations in the MFDI. While the shocks attributable to other variables like exchange rate and manufacturing exports are 5.3 percent and 10.5 percent respectively.

From the above results, it is quite evident that following conclusion can be made:

i) The result indicates that GDPm is the most exogenous variables in the system with only 39 percent of its forecast error variance being explained by other variables, while about 61 percent of the forecast error is attributable to its own shock.

ii) The result also shows that LEXR is the most interactive variable in the system because 95 percent of its forecast error variances are explained by LGDPm (58 percent), LCPI (14 percent), LEX (10 percent) and LEXR (5 percent).

iii) It is therefore strengthen the evidence of causality that move from LGDPm to MFDI i.e (LGDPm LMFDI).

\subsection{Impulse Response Functions}

Impulse Response Functions (IRFs) are one of the useful tools of the unrestricted VAR approach for examining the interaction between the variables in this study. They reflect how individual variables respond to shocks from other variables in the system. When graphically presented, the IFRs give a visual representation of the behavior of variables in response to shocks. The responses are for a particular variable in the system. As noted by 
Odusola and Akinlo, (2001), the interpretation of the impulse response functions takes into consideration the first differencing of the variables as well as the vector error correction estimates. The response forecast period is 50 years to enables us capture both the long-term and short-term responses. The results can be presented in the figure 2 below:
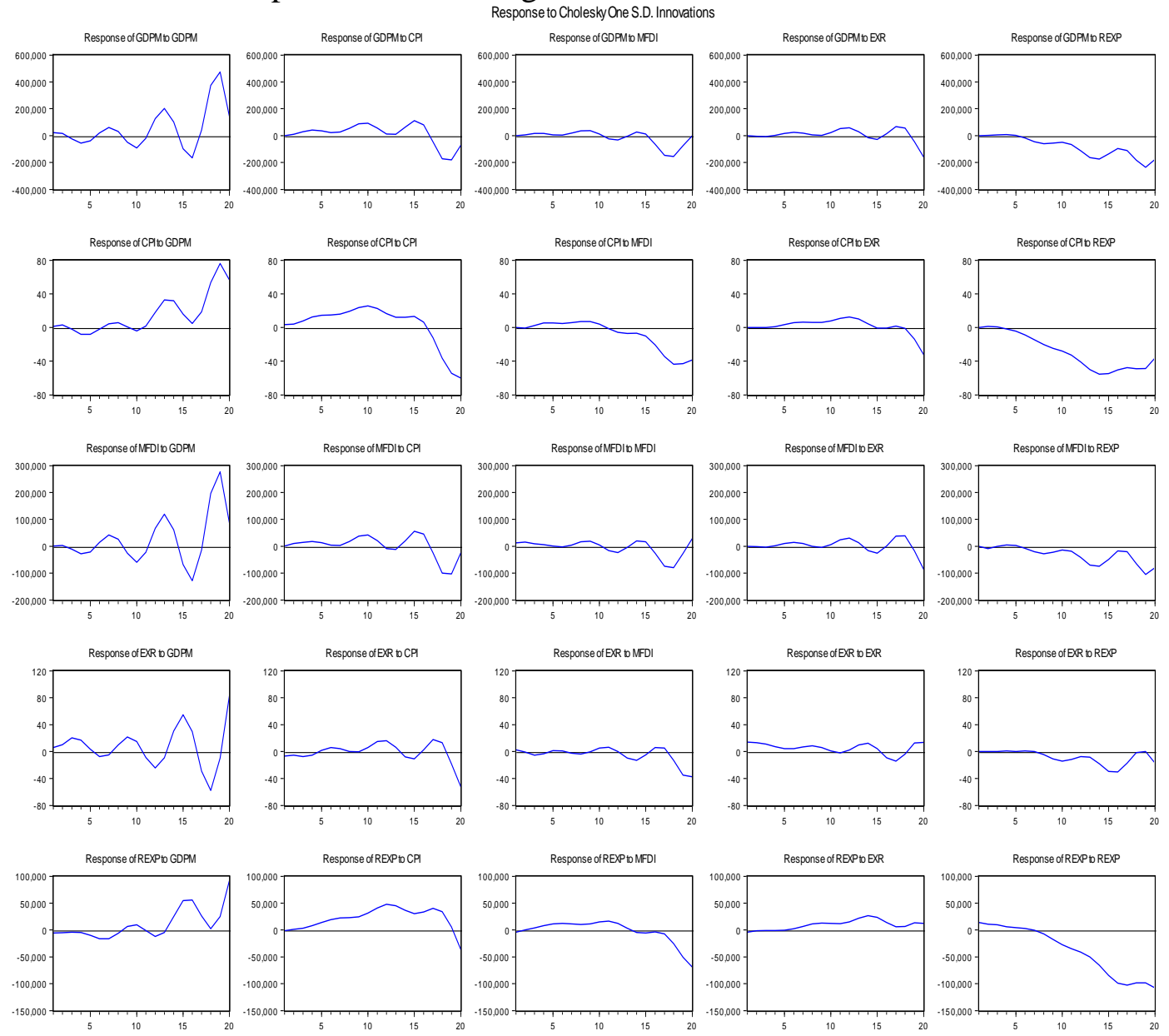

Figure 2: Generalized Impulse Response

Dynamic movements of each to one standard error shock to each other variables, particularly to the manufacturing gross domestic products (GDPm) are analyzed by using orthogonalised impulse response functions (IFRs) presented in figure below. According to the findings presented above, a one standard error shock to GDPm will leads to the expansion of manufacturing output in the long-run, since the effect of the shock on GDPm will be positive. 
The response of GDPm due to shock in CPI is positive up to 15 years period, but after that it is expected to become negative. By implication, price level is expected to decrease with the expansion in the manufacturing output in the long-run. While a standard shock to GDPm will lead to an increase in price level.

Furthermore, a standard error shock to GDPm leads to a positive effect on manufacturing foreign direct investment (MFDI) in the long-run. This tends to support the causality that runs from GDPm to MFDI. The market size of the economy as represented by the GDP has been one of the major determinants of FDI flow into the sector. While a standard error shock to MFDI leads to fall in the manufacturing output in the long-run.

In addition, the response of exchange rate (EXR) due to shock to GDPm is quite stable in the short-run, but become positive in the long-run. While the response of the GDPm due to shock to EXR become negative in the long-run. By implication, a one standard error shock to GDPm will lead to a depreciation of domestic exchange rate and as Nigeria economy is more open, the use of foreign reserve to cover current account deficit can lead to the depreciation of Naira exchange rate.

Finally, a one standard error shock to manufacturing exports (EXPm) will lead to a decrease in the GDPm in the long-run. While a response of manufacturing exports due to shock to GDPm is positive in the long-run. This result confirms the effectiveness of government's industrial and export incentives that were directed towards aiding exports in the manufacturing exports.

\subsection{Policy Implication and Recommendations}

Generally speaking, the manufacturing sector plays a catalytic role in a modern economy and has many dynamic benefits critical for economic transformation. In any advanced economy or even growing economy like Nigeria, the manufacturing sector is a leading sector in many respects. It is a pathway for increasing national out-put in relation to import replacement and export expansion, creating foreign exchange earning capacity, raising employment and per capita income which causes unique consumption patterns. In this study, it has been established that improvement in the output growth in manufacturing sector will impact positively in the FDI flows into the sector. To this end, efforts should be made by the government through monetary and fiscal policies designed to boost out-put in the sector. More so, efforts should be made to intensified the regulation of foreign exchange market, since foreign exchange allocation play a crucial role in the manufacturing out-put growth, efforts towards deregulation of the exchange rate allocation to non-oil exports, especially to manufacturing sector, though made the sector more competitive, but resulted in massive escalation of cost 
in the procurement of industrial inputs and this negatively affect manufacturing out-put. In addition, efforts should be made to make industrial climate more conducive for manufacturing activities. These include provision of basic infrastructural facilities that will enhance full utilization of industrial capacity. This conducive atmosphere will motivate the flow of foreign direct investment into the sector.

\section{References:}

1. Aiten, B. J., and Harrison, E. (1999), Do Domestic Firms Benefits from Direct Foreign Investment? Evidence from Venezuela. The American Economic Review, 89(3), 605-618.

2. Akinlo, A. E. (2004), Foreign Direct Investment and Growth in Nigeria: An Empirical Investigation, Journal of Policy Modeling, 26(5),627-639.

3. Asiedu, E. (2002), Capital Controls and Foreign Direct Investment, World Development, 32(3), 107-119.

4. Asiedu, E. (2001), On the Determinants of Foreign Direct Investments to Developing Countries: Is Africa different? World Development, 30(1),107-119.

5. Adenikinju, A. F. and Chete, L. N. (2002), Productivity, Market Structure and Trade Liberalization in Nigeria. African Economic Research Consortium (AERC), Research Paper, African Economic Research Centre, Nairobi.

6. Aliber, R. Z. (1970), A Theory of Direct Foreign Investment. In The International Corporation, Charles P. (Ed). Massachusetts: The MIT press.

7. Aliber, R.Z (1971), The Multinational Enterprise in a Multiple Currency World, In The Multinational Enterprise, J. H. Dunning (Ed). London: George Allen and Unwin Ltd.

8. Akinlo, A. E, (2003), Exchange Rate Depreciation and Currency Substitution in Nigeria, African Review of Money Finance and Banking, 85(3),139-143.

9. Alvarez, R., (2003), Inversion extranjeradirecta on Chile y suImpactoSobre la productividad.Departmento de Economia. Universidad de Chile. Retrieved May 19, 2004.From http/www.personal.ander. Ucla.Edu/Roberto.alvarez/paper IED. Pdf.

10. Bayoumi, T. and Eichengree B., (1994). Macroeconomic Adjustment under Bretton Woods and the post Bretton-Woods Float: an Impulse Response Analysis. The Economic Journal, (104), 813-827.

11. Buckley, P. J. (1985), A Critical View of The Theories of the Multinational Enterprise. In the Economic Theory of Multinational 
Enterprise, Buckley, P. J and M. Casson (ed.), New York: St Martin's Press.

12. Buckley, P. J. (1990), Problems and Developments in the Core Theory of International Business, Journal of International Business Studies, 21(4), 657-665.

13. Central Bank of Nigeria, (2010), Statistical Bulletins, Abuja, Nigeria.

14. Coase, R. H. (1937), The Nature of the Firm, Economica, 4(16),386405.

15. Chirwa, E. W. and Zakeyo, C. (2003), Impact of Economic and Trade Policy Reforms on Food Security in Malawi, Report Submitted to the Food and Agricultural Organisation FAO), Lilongwe, Malawi and the Africa Economic Research Consortium, AERC.

16. Caves, R. E. (1971), International Corporations: The Industrial Economics of Foreign Investment, Economica, 38(149), 1-27.

17. Caves, R. E. (1974), Multinational Firms, Competition and Productivity in the Host Country Markets, Economica, 41(162),176193.

18. Chete, L. N. Adeoti, J. O., Adeyinka, F. M. and Ogundele, O. (2013), Industrial Development and Growth in Nigeria, Working Paper No.8, Africa Growth Initiative at Brookings, African Development Bank Group and United Nations University UNU-WIDER.

19. Dadush, U., Dasgupta, D. and Ratha, D. (2000), The Role of Shortterm Debt in Recent Crises, Finance and Development, 37(4), 54-57.

20. Dunning, J, H. (1977), Trade, Location of Economic Activity and the MNE: A Search for an Eclectic Approach: In The International Allocation of Economic Activity, Bertil Ohlin et al (Eds). London: Macmillan.

21. Dunning, J. H. (1979), Explaining Changing Patterns of International Production: Some Empirical Tests, Journal of International Business Studies, 11(1),9-31.

22. Dunning. J. H. (1988), Explaining the International Direct Investment Position of Countries: Toward a Dynamic or Developmental Approach, WeltwirtchaftHichesArhiv 119(1), 30-64.

23. De Mello, L. (2002), Foreign Direct Investment-led growth: Evidence from time series and Panel Data, Oxford Economic Papers No. 51,133-151.

24. Dunning, J.H.(1993), Multinational and the global economy, Addison Wesley: Wokingham, England.

25. Ekanayake, E. M., Richard, V. and Veeramacheneni, B. (2003), Openness and Economic Growth: Empirical Evidence on the Relationship between Output, Inward FDI and Trade, Journal of Business Strategies, 20(1),59-72. 
26. Gokal, V. and Hanif, S. (2004), Relationship between Inflation and Economic Growth, , Economic Department, Reserve Bank of Fiji, Suva, Fiji, Working Paper No. 002.

27. Grosse, R. and Kujawa, D. (1995), International Business: Theory and Managerial Application. U.S: Irwin.

28. Haddad M. and Harrison A. (1993), Are there Positive Spillovers from Direct Foreign Investment? Evidence from Panel Data for Morocco, Journal of Development Economics, 42(1),51-74.

29. Inegbenebor, A. O. (1995), Size, Structure and Performance of Private Nigerian Manufacturing Enterprises: Nigerian Journal of Economics and Social Studies, 37(1), 13-27.

30. Kojima, K. (1973), A Macroeconomic Approach to Foreign Direct Investment, Hitotsubashi Journal of Economics, 14(1), 1-21.

31. Kojima, K. (1984), Micro-and Macro Economic Models of Foreign Direct Investment: Towards a synthesis, Histosubashi, Journal of Economics, 25(1), 1-20.

32. Kindleberger, C. P. (1984), Multinational Excursions, Cambridge, Mass: MIT Press.

33. Karbasi, A. E., Mahamadi, E.andGbofrani, S. (2005), Impact of Foreign Direct Investment on Economic Growth, Paper Presented at the $12^{\text {th }}$ Economic Research Forum Conference, $19^{\text {th }}-21^{\text {st }}$ December, Egypt.

34. Kohpaiboon, A. (2004), Foreign Trade Regimes and the FDI-Growth Nexus: A Case Study of Thailand, Journal of development studies, 40(2),55-69.

35. Lipsey, R. E. (2001), Foreign Direct Investment and Wages in Indonesian Manufacturing, NBER, Working Paper No. 8299.

36. Lipsey, R. and Sjoholm, F. (2004), Foreign Direct Investment Education and Wages in Indonesian Manufacturing, Journal of Development Economics, 73(1),415-422.

37. Mansouri, B. (2005), The Interactive Impact of FDI and Trade Openness on Economic Growth: Evidence from Morocco, Paper Presented at the $12^{\text {th }}$ Economic Research Forum (ERF) Conference, Cairo, December.

38. Morisset, J. (2000), Foreign Direct Investment in Africa: Policy also Matters, Transitional Corporations, 9(2),107-125.

39. Odusola, A. F. and Akinlo, A. E. (2001), Output, Inflation and Exchange Rate in Developing Countries: An Application to Nigeria, The Developing Economics, 39(2),39-42.

40. Okonjo-Iweala, N. and Osafo-Kwaako, P. (2007), Nigeria's Economic Reforms: Progress and challenges, Brookings Global 
Economy and Development, The Brookings Institution, Washington, DC 20036.

41. Oscar, B. and Simon, S. R. (1994), An Econometric Analysis of Foreign Investment in Spain, 1964-1989, Southern Economic Journal, 16(1), 104-120.

42. Oyelaran-Oyeyinka, B. (1997), Technological Learning in African Industry, A Study of Engineering Firms in Nigeria, Science and Public Policy, 24(5),309-318.

43. Ratha, D. (2000), Complementarity between Multilateral Lending and Private Flows to Developing Countries: Some Empirical Results, Policy Research, World Bank Working Paper No. 2746.

44. Rettab, B. Rao, A. and Charif, H. (2009), Why Do Firms Venture in External markets?The case of Dubai, International Research, Journal Finance and Economics, 29(1), 146-159.

45. Rugman, A. M. (1979), International Diversification and the Multinational Enterprise, Lexington, KY: D.C Health.

46. Sun, H. (1996), Macro-Economic Impact of Direct Foreign Investment in China:1977-1993, Department of Economics, University of Sydney, Australia. Working Papers in Economics, No 232.

47. Ubok-Udom, E. (1999), Currency Depreciation and Domestic Output Growth in Nigeria, The Nigeria Journal of Economics and Social Studies, 5(5),1-12.

48. Venon, R. (1979), International Investment and International Trade in the Product Life Cycle, Quarterly Journal of Economics, 80(1),190207. 
Table 6: Generalized Variance Decomposition (VDCs) results Variance Decomposition of GDPm

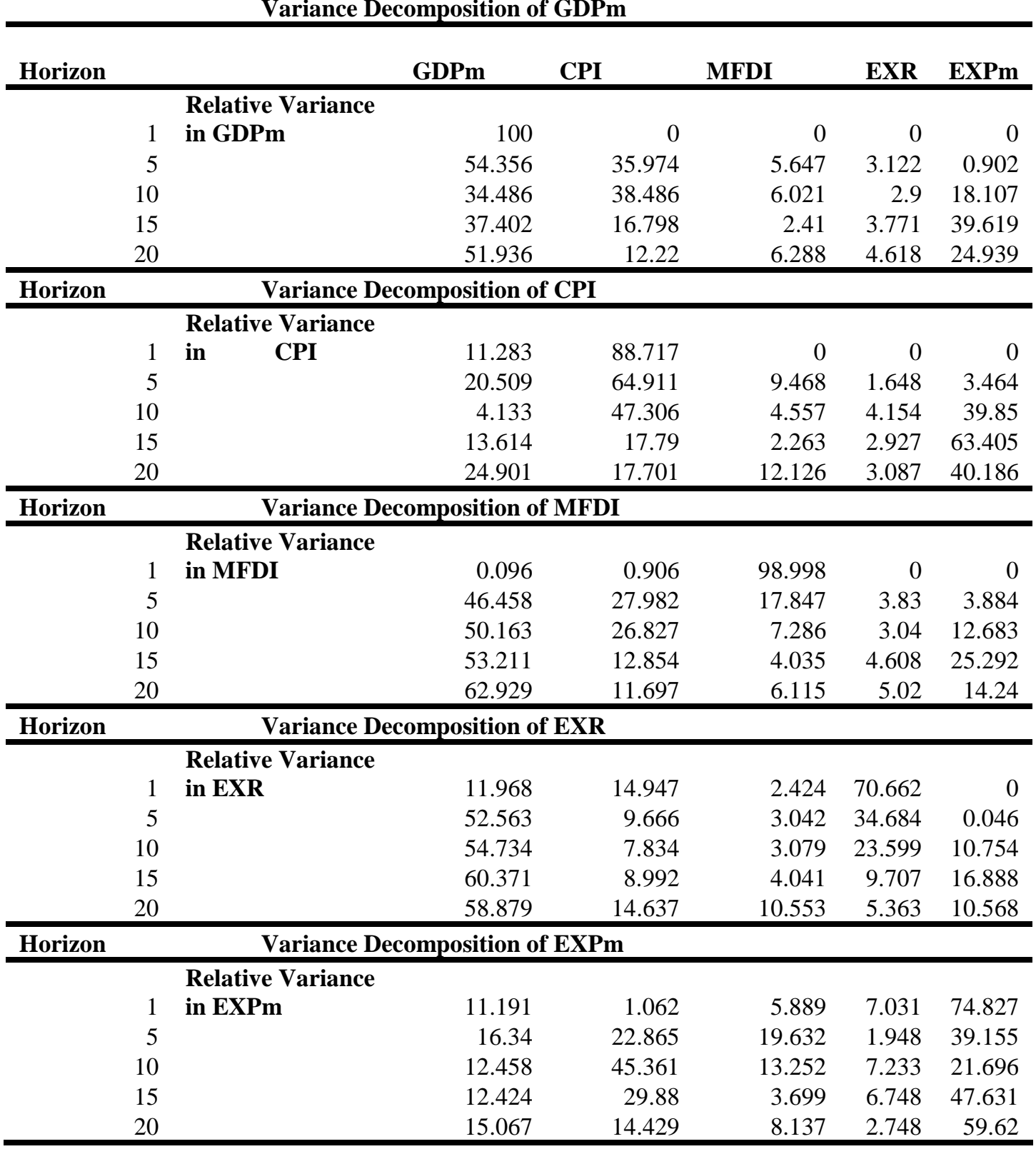

